\title{
Art as an instrument to develop a critical approach
}

We continue with our series of articles regarding Art as an educational tool in medicine, based on the proposal to use art's symbolic language as a teaching resource in health care professional training. ${ }^{1}$

This time, we will analyze the nature and versatility of critical approach in light of a poem written by the great Fernando Pessoa, using his heteronym Alexander Search, "Mania of Doubt":

"All things unto me are queries Emerging swiftly from evidence alike Things are and seem, and nothing bears The secret of the life it wears Learning that the clearer all things reveal The greater mystery they conceal.»

A critical approach implies cleverly assessing not only other people's work, but particularly our own, through a self-demanding and persistent perspective so that we give our very best. ${ }^{3}$ As a result, practicing such approach translates into benefits for both patients and physicians, as we will see below.

In a previous article ( $«$ Art as an instrument to understand the difference between disease and having a disease»), we analyzed the difference between the pathophysiological process that affects an individual (the sick person) and the theoretical construct developed to interpret it (the disease). ${ }^{4}$ A physician's critical approach is precisely what allows them to reduce their margin of error by means of a constant reexamination of the accuracy of their interpretations, therefore bringing their diagnoses closer to reality and, as a result, bringing their prescriptions closer to therapeutic success.

In addition, physicians capable of assessing potential improvements by admitting their own and other's ignorance and errors learn to practice critical thinking, to learn and unlearn (Alvin Toffler), therefore pursuing the only possible path towards transformation and professional and spiritual growth.,

Finally, it must not be forgotten that curious ignorance (James Clerk Maxwell) functions as an engine to look for and acquire knowledge; ultimately, such knowledge consists in getting answers that lead to new questions, that is to say, going from ignorance to docta ignoratia (Nicholas of Cusa). ${ }^{78}$

To sum up, acquiring a critical approach is critical for an optimal medical and personal practice and development, and art may be a useful resource to this end.

Carlos G. Musso, M.D. and Paula A. Enz, M.D. School of Medicine, Instituto Universitario del Hospital Italiano de Buenos Aires - Argentina

http:/ /dx.doi.org/10.5546/aap.2016.eng.100

\section{REFERENCES}

1. Musso CG, Enz PA. El arte como instrumento educativo en medicina. Arch Argent Pediatr 2014;112(6):494-5.

2. Pessoa F. Máscaras y paradojas. Barcelona: Eldhasa; 1996.

3. Ceriani Cernadas JM. La actitud crítica en medicina: cada vez más necesaria. Arch Argent Pediatr 2012;110(3):194-5.

4. Musso CG, Enz PA. El arte como instrumento para comprender la diferencia entre el enfermo y la enfermedad. Arch Argent Pediatr 2015;113(4):292-3.

5. Bartels D. Las buenas preguntas: No es en el aula donde mejor se aprende a pensar de forma crítica. Investigación y ciencia 2013;444:56.

6. Jung C. El Libro Rojo. Buenos Aires: El hilo de Ariadna, 2012.

7. Palma H. Filosofía de la ciencia. San Martin: UNSAM. 2010.

8. Firestein S. Ignorance: How it drives Science. Oxford : Oxford University Press; 2012. 